\title{
O SISTEMA PÚBLICO DE PENSIÓNS EN GALICIA: ELEMENTOS DIFERENCIAIS DENTRO DO ESTADO ESPAÑOL
}

\author{
Miguel A. Vázquez Taín \\ Universidade de Santiago de Compostela \\ miguel.vazquez.tain@usc.es
}

RESUMO: Este traballo analiza o sistema público de pensións contributivas en Galicia e no conxunto do Estado español. Malia que o sistema de pensións é único en España, presenta elementos diferenciais a nivel territorial que singularizamos para o caso galego. Aspectos como o número e a evolución de pensionistas e pensións do sistema, a súa contía, a súa distribución por modalidades e polos reximes nos que se causan, a taxa de cobertura poboacional, a relación entre cotizantes e pensionistas e, como sistema contributivo, os gastos e ingresos do mesmo, son elementos básicos para avaliar a realidade actual e as perspectivas de futuro do sistema de pensións en Galicia e no conxunto do Estado. Na case totalidade das variables estudadas, se o sistema se analiza a nivel territorial, Galicia presenta peores indicadores que a súa media. Aínda que a estrutura económica e laboral, pasada e presente, condiciona a realidade dun sistema de pensións de repartimento, en Galicia incide en maior medida a súa estrutura poblacional que, de individualizarse e separarse territorialmente do sistema, hipotecaría a súa viabilidade futura.

Palabras chave: Pensións / Seguridade Social / Cotizacións Sociais / Avellentamento Poboacional

\section{The public system of pensions in Galicia: differential elements inside the Spanish State}

ABSTRACT: This work analyzes the public system of contributory pensions in Galicia and in the Spanish State as a whole. Although the pension system is unique in Spain, it presents differential elements at territorial level that we single out for the Galician case. Aspects such as the number and evolution of pensioners and the pension system, its amount, distribution patterns and by the schemes in which they cause, the rate of population coverage, the relationship between contributors and pensioners and, as contributory system, its expenditure and revenue, are basic elements to assess the current reality and future prospects of the pension system in Galicia and in the whole of the State. In almost all the variables studied, if the system is scanned at territorial level, Galicia shows worse indicators than its average. Although the past and current economic and employment structure conditions the reality of a system of funded pensions, in Galicia it affects more of its population structure whose system, individualized and territorially separated, risks jeopardising its future viability.

Keywords: Pensions / Social Security / Social Contributions / Population Ageing

\section{INTRODUCIÓN}

Os sistemas públicos de pensións configuráronse nos últimos anos como un dos piares básicos do estado de benestar nos países desenvolvidos. España non foi allea a esta realidad e dotouse dun modelo que, aínda que robusto na súa orixe, a crise económica introduciu nun proceso de debate permanente con respecto á súa viabilidade futura, á que queremos contribuír neste traballo analizando os principais elementos que o configuran. Malia que o sistema é único para todo o Estado español, presenta realidades territoriais diferentes sobre as que nos parece oportuno profundar dende a perspectiva de Galicia.

Á hora de afrontar a análise das pensións en España, debemos ter en conta que están integradas por unha modalidade contributiva e unha non contributiva, incluíndose dentro da primeira tanto as da Seguridade Social como as das Clases Pasivas do Estado.

O sistema contributivo da Seguridade Social (SS) é de natureza profesional e obrigatoria, e xera o dereito a ser beneficiario dunha pensión se se cumpren unha serie de requisitos, 
entre os que destaca ter cotizado un período mínimo - de carencia, establecido actualmente en 15 anos-, e ter acadado a idade legal de xubilación -agora en proceso de incremento progresivo ata acadar os 67 anos o 1 de xaneiro de 2027. Financiase coas cotizacións sociais pagadas por empresas e traballadores á SS que, como sistema de repartimento, aplícanse contemporaneamente o pago das pensións en vigor en cada momento.

O Rexime Especial de Clases Pasivas constitúe un esquema especial que dá cobertura ao sistema de pensións dos funcionarios públicos dos corpos administrativos, xestionado directamente pola Subdirección Xeral de Clases Pasivas do Ministerio de Facenda e Administracións Públicas, que se foi asimilando nos últimos anos ao Rexime Xeral (RX) da SS, ata o punto de que o 1 de xaneiro de 2011 pechouse definitivamente á entrada de novos cotizantes, que agora son adscritos directamente ao RX. Isto supón, na práctica, que este rexime se atopa en fase de extinción, se ben perdurará durante moitos anos, pois aínda hai moitos pensionistas e beneficiarios do mesmo que se irán incorporando nos próximos anos. Finánciase nun 90\% con asignacións orzamentais, que se poden equiparar ás cotizacións empresariais do RX, e o $10 \%$ restante mediante cotizacións dos traballadores adscritos ao mesmo.

No sistema español de pensións contémplase tamén o recoñecemento de pensións de incapacidade e xubilación para aqueles residentes en España que non puideron completar o período mínimo de cotización, ou non cotizaron en absoluto, esixíndose nestes supostos a percepción de ingresos por debaixo duns límites determinados, así como outras circunstancias personais ou familiares. Este sistema non contributivo finánciase con cargo aos Presupostos Xerais do Estado, se ben o seu recoñecemento e xestión corresponde ás Comunidades Autónomas que teñen transferidos os servizos do Instituto de Maiores e Servizos Sociais (IMSERSO), agás nas cidades autónomas de Ceuta e Melilla, nas que as xestiona directamente o IMSERSO.

Figura 1: 0 sistema público de pensións. Ano 2015

\begin{tabular}{|c|c|c|c|c|c|c|}
\hline & \multicolumn{2}{|c|}{ Seguridad Social } & \multicolumn{2}{|c|}{ Clases Pasivas } & \multicolumn{2}{|c|}{ Pensiones no Contributivas } \\
\hline & Galicia & España & Galicia & España & Galicia & España \\
\hline Pensionistas / beneficiarios ${ }^{\text {(a) }}$ & 662.832 & 8.458 .648 & 41,427 & 591.825 & ad. & n.d. \\
\hline Pensiones / prestaciones ${ }^{\text {(a) }}$ & 750.727 & 9.304 .555 & 43.219 & 615.208 & 41.835 & 453.547 \\
\hline Antas de pensiones & 40,474 & 541.894 & 2.368 & 34.223 & n.d. & nd. \\
\hline Bajas de pensiones & 38.336 & 468.128 & 1.885 & 29.986 & nid. & n.d. \\
\hline Gasto total pensiones (millones 6 ) & 7.829 .50 & 115.068 .71 & 928,18 & 13068.95 & 218.81 & 2371,11 \\
\hline Gasto total pensiones en $\% \mathrm{~PB}$ & $14,24 \%$ & $10,64 \%$ & $1,69 \%$ & $1,21 \%$ & $0,40 \%$ & $0,22 \%$ \\
\hline
\end{tabular}

Modula anda:

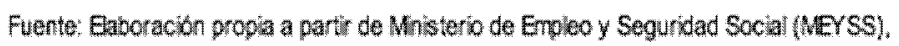

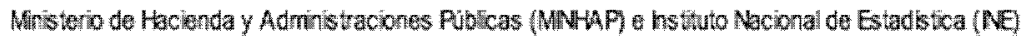

Na Figura 1 recollemos as principais magnitudes dos diferentes esquemas de pensións públicas, tanto para Galicia como para o conxunto do Estado español, no ano 2015. O sistema da dá cobertura a máis de 9,5 millóns de pensionistas ou beneficiarios, cun gasto total que representa un 12\% do PIB español. Estas cifras son máis significativas en termos 
relativos para Galicia, onde cobre a unhas 746 mil persoas, -o 27,3\% da poboación- e implica un gasto que representa o 16,3\% do PIB galego.

Encadrado o marco xeral e as magnitudes máis representativas do sistema público de pensións en Galicia e en España, neste traballo centrarémonos, pola súa importancia relativa e polas singularidades do mesmo, exclusivamente na parte contributiva da Seguridade Social, analizando os aspectos diferenciais que presenta o sistema na Comunidade Autónoma de Galicia.

\section{BENEFICIARIOS E PENSIÓNS DO SISTEMA}

O sistema contributivo da SS deu cobertura en Galicia a 662.832 pensionistas de media no ano 2015, o que supón o 7,84\% do total nacional de beneficiarios, porcentaxe significativamente superior ao 5,86\% que representa a poboación galega no conxunto de España. Este número de pensionistas experimentou un forte crecemento entre os anos 1990 e 2005, nos que pasou dos 480 aos 608 mil beneficiarios, -un crecemento medio anual do $1,6 \%$, que sumou un total do $26 \%$, moderando o seu ritmo de crecemento nos últimos 10 anos, nos que a taxa media de incremento anual baixou ao 0,85\%, inferior á evolución do número de pensionistas no total nacional do sistema, na que a taxa media de crecemento foi do 1,43\% (ver Figura 2). Unha evolución semellante presenta o número de pensións pagadas polo sistema que, en comparación co número de pensionistas, superan a estes nun 13\% en Galicia e nun 10\% en España. Debemos ter en conta que o sistema contributivo permite cobrar aos pensionistas máis dunha pensión, se se xerou dereito a ela e sempre dentro dos límites máximos establecidos.

Figura 2: Evolución do número de pensionistas e pensións do sistema

\begin{tabular}{|c|c|c|c|c|c|c|c|c|}
\hline \multirow{2}{*}{ Añ̄o } & \multicolumn{2}{|c|}{$\mathrm{N}^{\mathrm{s}}$ Pensionistas } & \multicolumn{2}{|c|}{ Pensionistas 2005 $=100$} & \multicolumn{2}{|c|}{ N Pensiones } & \multicolumn{2}{|c|}{ Peso relativo Galicia } \\
\hline & Galieia & España & Galicia & España & Galicia & España & Pensionistas & Pensiones \\
\hline 2005 & 608.544 & 7.336 .848 & 100,0 & 100.0 & 689.744 & 7.979 .707 & $8.29 \%$ & $8.64 \%$ \\
\hline 2006 & 613.580 & $7,441,838$ & 100,8 & 101,4 & 697,498 & 8.165 .336 & $8,25 \%$ & $8.54 \%$ \\
\hline 2007 & 617.743 & 7.533 .971 & 101,5 & 102,7 & 702,445 & 8.273 .939 & $8,20 \%$ & $8,49 \%$ \\
\hline 2008 & 622.852 & 7.635 .600 & 102,3 & 104,0 & 708.539 & 8.390 .796 & $8,16 \%$ & $8,44 \%$ \\
\hline 2009 & 628.657 & 7.761 .549 & 103,3 & 105.7 & 714,922 & 8.531 .935 & $8,10 \%$ & $8,38 \%$ \\
\hline 2010 & 634.314 & 7.886 .409 & 104,2 & 107,3 & 720.992 & 8.671 .018 & $8,04 \%$ & $8,34 \%$ \\
\hline 2011 & 640.518 & 8.007 .062 & 105,1 & 108,8 & 727,552 & $8.805,164$ & $8,00 \%$ & $8,26 \%$ \\
\hline 2012 & 645.390 & 8.110 .394 & 105,9 & 110.1 & 732.717 & 8.919 .997 & $7,96 \%$ & $8.21 \%$ \\
\hline 2013 & 651.581 & 8.243 .054 & 106,9 & 111,7 & 739.114 & 9.065 .830 & $7,90 \%$ & $8,15 \%$ \\
\hline 2014 & 658.129 & 8.365 .598 & 107,9 & 113,2 & 746.031 & 9.201 .080 & $7,87 \%$ & $8,11 \%$ \\
\hline 2015 & 662.832 & 8.458 .642 & 108,6 & 114,3 & 750.727 & 9.304 .555 & $7,84 \%$ & $8,07 \%$ \\
\hline
\end{tabular}

Fuente: Baboracion propia partín de MEYSS

Se analizamos o peso relativo do número de pensionistas con respecto á poboación total -(véxase Figura 3 no Anexo), atopamos que o 24,3\% da poboación galega é beneficiaria do sistema, fronte ao $18,1 \%$ do total nacional, crecendo esta ratio proporcionalmente máis en Galicia durante o período analizado, a pesar do menor incremento do número de pensionistas. Isto débese á caída da poboación galega dende o ano 2005 nun 0,5\%, fronte ao incremento do $6 \%$ do total nacional.

Se nos centramos na cobertura do sistema por estratos de idade da poboación, como facemos na Figura 4 para o ano 2015, constátase que da poboación galega de 65 anos ou máis, que representaba o 24,1\% da poboación total de Galicia, o 79,94\% era beneficiaria do sistema como pensionista, sendo menor ese grao de cobertura no total nacional, no que 
só acadaba o 76\%. Diferenzas similares danse na cobertura mediante pensións á poboación de 64 anos ou menos, con índices do 6,67\% e 5,10\% respectivamente en Galicia e en España.

Figura 4: Cobertura do sistema por estratos de poboación. Ano 2015

\begin{tabular}{|c|c|c|c|c|c|c|}
\hline & \multicolumn{2}{|c|}{ Población } & \multicolumn{4}{|c|}{ Pensionistas } \\
\hline & $\begin{array}{c}65 \text { años } \\
\text { o más }\end{array}$ & $\begin{array}{c}\% / \\
\text { TOTAL }\end{array}$ & $\begin{array}{c}65 \text { años } \\
\text { o más }\end{array}$ & $\begin{array}{c}\% \text { / Población } \\
65 \text { años o más }\end{array}$ & $\begin{array}{l}64 \text { años } \\
\text { o menos }\end{array}$ & $\begin{array}{c}\% / \text { Población } \\
64 \text { afnos o menos }\end{array}$ \\
\hline Gallela & 655.907 & $24,01 \%$ & 524.305 & $79,94 \%$ & 138.527 & $6,67 \%$ \\
\hline España & 8.573 .985 & $18,39 \%$ & 6.516 .587 & $76,00 \%$ & 1.942 .055 & $5,10 \%$ \\
\hline
\end{tabular}

Fuente: Baboracion propia a partir de NE y MEY SS.

Polo que respecta á distribución do número de pensións atendendo ao seu tipo (ver Figuras 5 e 6), en Galicia o groso das mesmas correspóndese ás de xubilación, que representan o $62 \%$ do total, seguidas das pensións de viuvez, que supoñen o $25 \%$, e as de incapacidade permanente, co 9,1\%, tendo unha importancia marxinal as de orfandade, co $3,2 \%$, e as outorgadas a favor de familiares, co 0,8\%. En relación coa súa evolución durante o período 2005 a 2015, destaca a diminución nos últimos anos das pensións correspondentes á incapacidade permanente, polas maiores restricións que, froito dos desequilibrios económicos do sistema, impuxéronse para acceder ás mesmas, e o incremento significativo das de orfandade, que nos últimos 4 exercicios creceron moi por enriba da media do total de pensións.

Figura 5: Evolución do número de pensións en Galicia por tipo

\begin{tabular}{|l|r|r|r|r|r|r|}
\hline Año & Incapacidad & Jubilación & Vludedad & Orfandad & $\begin{array}{c}\text { Favor } \\
\text { familares }\end{array}$ & Total \\
\hline $\mathbf{2 0 0 5}$ & 62.629 & 428.529 & 173.040 & 20.354 & 5.191 & 689.744 \\
$\mathbf{2 0 0 6}$ & 64.082 & $\mathbf{4 3 2 . 5 6 6}$ & 175.462 & 20.100 & 5.288 & 697.498 \\
$\mathbf{2 0 0 7}$ & 65.833 & 433.815 & 177.650 & 19.873 & 5.274 & 702.445 \\
$\mathbf{2 0 0 8}$ & 67.504 & 436.037 & 179.795 & 19.870 & 5.333 & 708.539 \\
$\mathbf{2 0 0 9}$ & 68.332 & 439.972 & 181.196 & 19.987 & 5.434 & 714.922 \\
$\mathbf{2 0 1 0}$ & 69.142 & 443.556 & 182.628 & 20.140 & 5.526 & 720.992 \\
$\mathbf{2 0 1 1}$ & 69.793 & 448.089 & 183.847 & 20.197 & 5.626 & 727.552 \\
$\mathbf{2 0 1 2}$ & 69.947 & 451.333 & 184.920 & 20.797 & 5.720 & 732.717 \\
$\mathbf{2 0 1 3}$ & 69.563 & 456.136 & 185.773 & 21.947 & 5.695 & 739.114 \\
$\mathbf{2 0 1 4}$ & 68.936 & 461.602 & 186.565 & 23.144 & 5.784 & 746.031 \\
$\mathbf{2 0 1 5}$ & 68.546 & 465.515 & 186.813 & 23.931 & 5.922 & 750.727 \\
\hline
\end{tabular}

Fuente: Eaboración propia a partir de MEY $\mathrm{SS}$.

Na comparativa co total do sistema a nivel nacional, a distribución do número de pensións por modalidades non presenta diferenzas significativas, tendo maior peso relativo en Galicia as de xubilación e as outorgadas a favor de familiares, fronte ás de incapacidade permanente, viuvez e orfandade, que presentan porcentaxes maiores no conxunto do sistema. Polo que respecta á súa evolución, destaca o maior crecemento das de xubilación no conxunto do Estado, que crecen por enriba da media do total de pensións, con taxas de incremento medio do 1,89\% nos últimos dez anos, fronte ao crecemento dese mesmo tipo de pensións en Galicia, de tan só o 0,89\%. A diferente evolución deste tipo de pensións explica a dinámica do seu total, que crecen un 1,55\% de 
media anual no conxunto do sistema fronte ao $0,85 \%$ en Galicia, ao presentar o resto de modalidades de pensións unha evolución semellante. No anexo analizamos a evolución.

Figura 6: Peso relativo dos diferentes tipos de pensións. \% sobre o total. Ano 2015

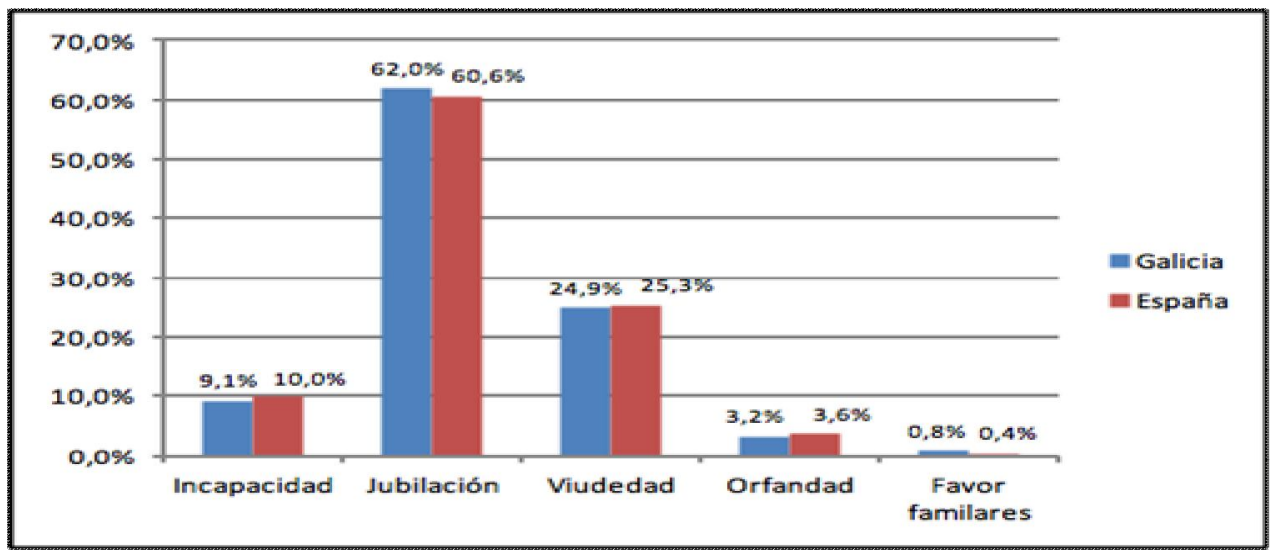

Fonte: elaboración propia a partir do MEESS (Ministerio de Emprego e Seguridade Social)

\section{CONTÍA DAS PENSIÓNS}

A contía que cobran os pensionistas está relacionada co tipo de pensión e o rexime no que son causadas, sendo moi diferentes as condicións de elixibilidade de cada categoría e as circunstancias de cotización en cada rexime. Polo xeral, nas pensións de xubilación e de incapacidade permanente o seu importe está ligado ás bases de cotización dos causantes, sendo a súa contía superior ás de viuvez, e estas, á súa vez, superiores ás de orfandade.

Na Figura 11 recollemos o importe e a evolución das pensións medias en Galicia por categorías que, no seu conxunto, tan só representan o $84,4 \%$ da media nacional, observándose unha pequena aproximación en termos porcentuais nos últimos anos, malia que se incrementan as diferenzas en magnitudes absolutas -(ver Figura 12). Asemade, se ben a súa contía en euros correntes presenta un incremento constante ao longo do período analizado, este foise reducindo ata ser inferior ao 2\% nos anos 2014 e 2015. Debemos ter en conta que na evolución da pensión media incide non só a porcentaxe da súa revalorización anual -limitada nos anos referidos ao 0,25\%, senón tamén a diferenza entre as pensións que se incorporan ao sistema e as que saen del, cousa que analizaremos máis adiante.

A pensión media en Galicia situouse nos 748 euros no ano 2015, sendo as de xubilación as que presentan maior importe, con 847 euros de media. Aínda que lles seguen cun importe semellante as de incapacidade permanente, cobran especial importancia, polo seu peso relativo, as de viuvez que, con 533 euros, tan só acadan o 63\% da contía das de xubilación.

Ao analizar o importe da pensión media por comunidades autónomas, atopámonos con que Galicia, xunto con Extremadura, é a que presenta unha contía máis baixa, acadando como se recolle na Figura 13 no Anexo- só o 68\% da pensión media do País Vasco, que ocupa o primeiro lugar. Estas desigualdades teñen a súa orixe nos diferentes pesos relativos e condicións das modalidades e reximes nos que se causan as pensións, estando tamén correlacionadas, como é lóxico, coas necesidades de complemento ata os mínimos legalmente establecidos, constatándose que os territorios con maior porcentaxe de pensións con complemento a mínimos son os que presentan menores contías media nas pensións, como podemos ver na Figura 14, no Anexo. En Galicia, o 33\% das pensións teñen complemento a mínimos fronte ao $26,5 \%$ de media no conxunto do Estado. 
Figura 11: Evolución da pensión media en Galicia por tipos de pensións. (Euros)

\begin{tabular}{|c|c|c|c|c|c|c|c|c|}
\hline \multirow{2}{*}{ Año } & \multirow{2}{*}{ Incapacidad } & \multirow{2}{*}{ Jubilación } & \multirow{2}{*}{ Viudedad } & \multirow{2}{*}{ Orfandad } & \multirow{2}{*}{$\begin{array}{c}\text { Favor } \\
\text { familiares }\end{array}$} & \multicolumn{3}{|c|}{ Todas } \\
\hline & & & & & & C & Increm. & Galicia/España \\
\hline 2005 & 595,85 & 557.66 & 381,05 & 257,23 & 328,03 & 506,23 & - & $83,0 \%$ \\
\hline 2006 & 626,26 & 590,74 & 399,76 & 277,46 & 348,33 & 535,10 & $5,70 \%$ & $83,4 \%$ \\
\hline 2007 & 650,98 & 622.53 & 417,86 & 292,55 & 368,81 & 562.19 & $5,06 \%$ & $83,4 \%$ \\
\hline 2008 & 686,41 & 667,65 & $4,43,69$ & 317,31 & 395,51 & 600.73 & $6,86 \%$ & $83,5 \%$ \\
\hline 2009 & 714,95 & 700.77 & 464,71 & 334,31 & 411,20 & 629,85 & $4,85 \%$ & $83,5 \%$ \\
\hline 2010 & 735,55 & 726.29 & 480,26 & 345,72 & 420,66 & 651.88 & $3,50 \%$ & $83,6 \%$ \\
\hline 2011 & 756,15 & 752,97 & 493,24 & 354,91 & 433,95 & 674.13 & $3,41 \%$ & $83,7 \%$ \\
\hline 2012 & 775.46 & 780.30 & 506.51 & 362.07 & 448.37 & 696,28 & $3.29 \%$ & $83,9 \%$ \\
\hline 2013 & 798,12 & 809,90 & 520,91 & 366,65 & 462,22 & 720,32 & $3,45 \%$ & $84,1 \%$ \\
\hline 2014 & 807,10 & 828,53 & 526,93 & 364,40 & 466.44 & 733,92 & $1,89 \%$ & $84,3 \%$ \\
\hline 2015 & 816,01 & 847,51 & 533,26 & 364,86 & 470.89 & 748.08 & $1,93 \%$ & $84,4 \%$ \\
\hline
\end{tabular}

Fuente: Eaboracion propa a parte de meyss.

Figura 12: Evolución da pensión media en Galicia e España. (Euros)

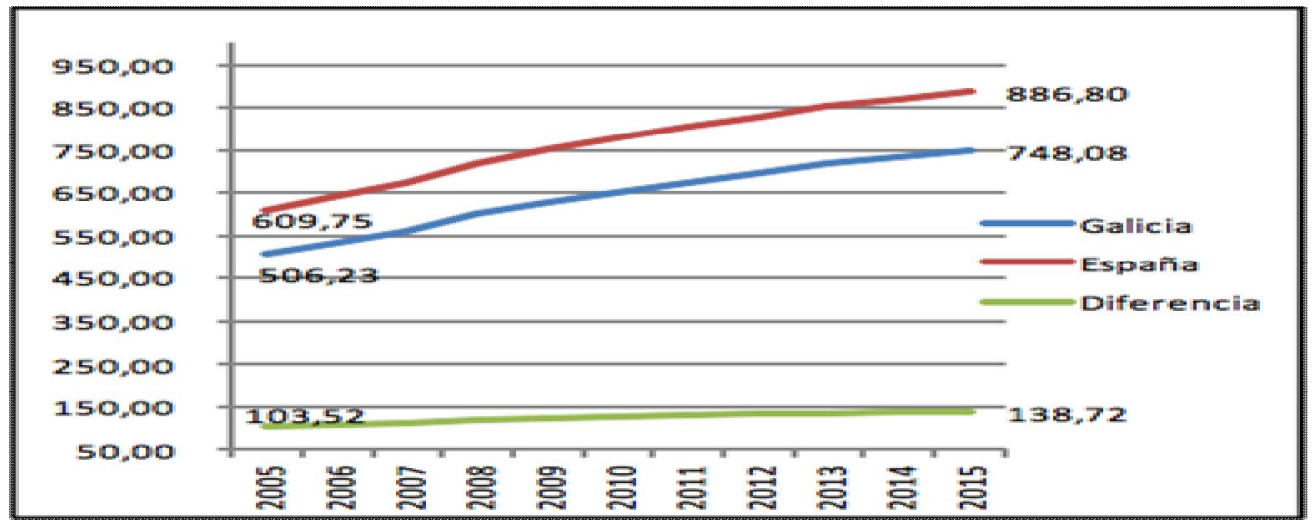

Fonte: elaboración propia a partir do MEESS

Se recollemos os importes das pensións medias por categorías e reximes en Galicia no ano 2015 -(ver Figuras 15 y 16), e realizamos a comparación co conxunto do Estado, pódese comprobar que, no que a tipos de pensións se refire, as pensións máis altas son as de xubilación que, asemade, son as que maiores diferenzas amosan con respecto á media nacional, representando en Galicia tan só o 82,9\% daquelas. No que aos reximes se refire, as diferenzas son aínda máis significativas, correspondendo os maiores importes ao Rexime Especial da Minería, ao de Enfermidades Profesionais e ao de Accidentes de Traballo, se ben o seu peso é moi pequeno no conxunto das pensións, tanto en Galicia como no total do sistema. Aínda que as pensións medias en Galicia no RX, no RETA e no Rexime Especial de Traballadores do Mar representan o $89 \%$, o $87 \%$ e o $92 \%$ respectivamente da media deses reximes no total nacional, a maior proporción de pensións do RETA na nosa Comunidade e o seu menor importe, fan que as diferenzas se incrementen ao comparar as medias totais. 
Figura 15: Pensión media por tipos de pensións. Ano 2015. (Euros)

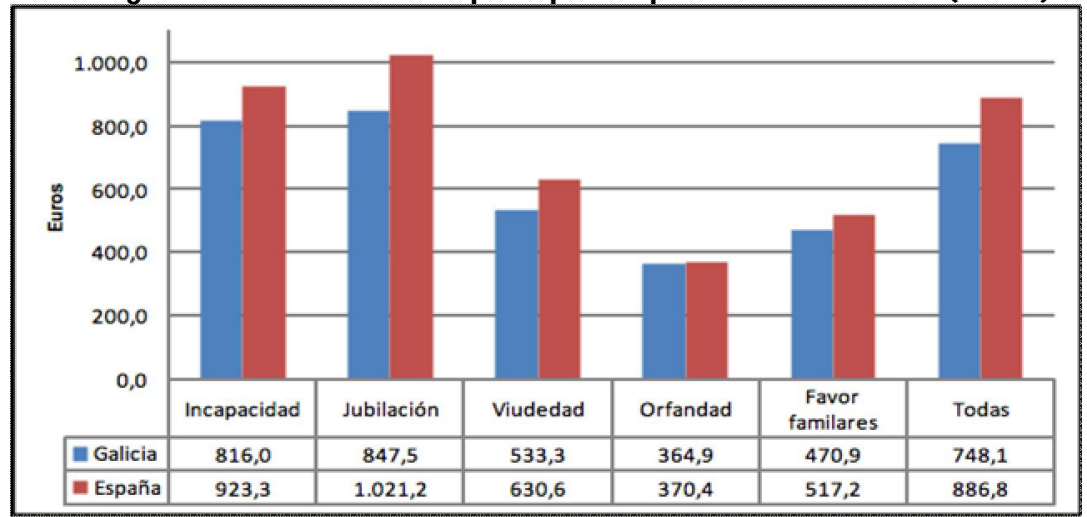

Fonte: elaboración propia a partir do MEESS

Figura 16: Pensión media por rexime. Ano 2015. (Euros)

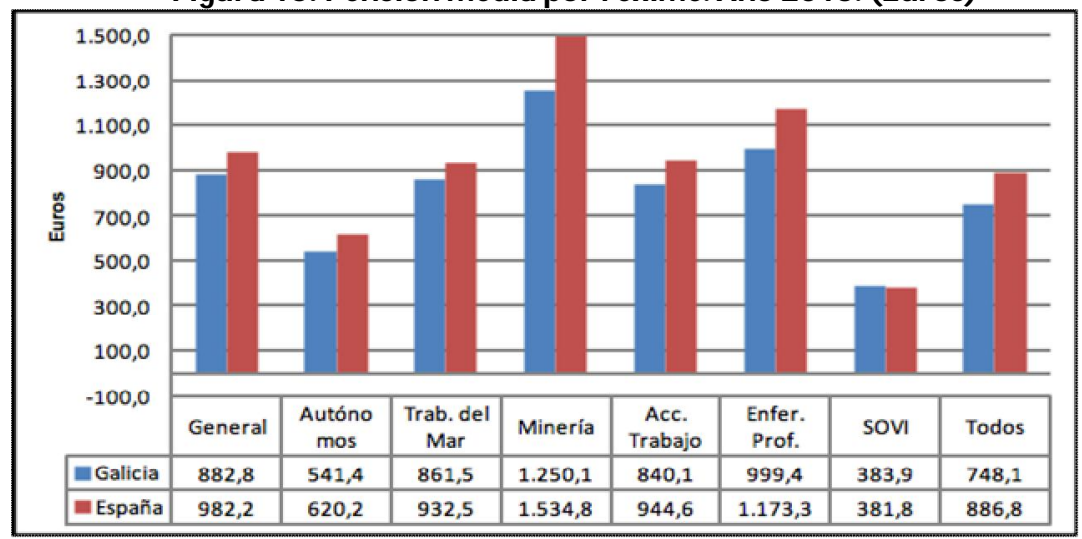

Fonte: elaboración propia a partir do MEESS

Á hora de analizar a evolución do gasto total en pensións, xunto coas contías medias e o número de pensións, resulta moi clarificador comparar as contías das novas pensións que se incorporan ao sistema cás que causan baixa no mesmo. Este exercicio facémolo nas Figuras 17 e 18, nas que recollemos os importes medios para os diferentes tipos de pensións en Galicia e no conxunto do sistema.

A contía das novas pensións supera nun $20 \%$ en Galicia, e un 18\% no total nacional, ao importe da pensión media, concentrándose estas diferenzas case exclusivamente nas de xubilación, para as que a distancia entre unhas e outras en Galicia é de máis do 37\%. Esta diferenza cobre abondo a caída nas contías das novas pensións de orfandade e a favor de familiares, situándose as pensións de viuvez e incapacidade permanente que entran no sistema practicamente na media do conxunto da súa categoría. Resulta chamativo e preocupante, dende a perspectiva de Galicia, que no referente aos importes medios das novas incorporacións ao sistema, apenas se corrixen as diferenzas entre a media galega e a nacional, representando aquela, para o total de pensións novas, o 85\% da desta.

No que ás baixas se refire, o seu importe sitúase un 11\% por debaixo da pensión media en Galicia, porcentaxe que se reduce ata o 9\% para o conxunto do sistema. Estas diferenzas son máis ou menos homoxéneas entre as diferentes categorías de pensións, agás para as outorgadas a favor de familiares, nas que se dobran estas porcentaxes, e as de incapacidade permanente, que se comportan de forma contraria ao ser os importes medio das baixas superiores aos importes medio do total das pensións deste tipo. 
Se poñemos en relación os importes medio das novas pensións cos das que causan baixa no sistema -(ver Figura 19), vemos como esa proporción é maior de media en Galicia que no total do sistema, $135 \%$ fronte ao 130\%, concentrándose principalmente nas pensións de xubilación, nas que, cunha proporción do $152 \%$, supera en 11 puntos a media nacional. Estas diferenzas teñen a súa orixe nas menores contías medias das pensións incorporadas en Galicia hai anos, principalmente por se xerar no rexime agrario, que agora se substitúen por pensións noutros reximes de maiores importes.

\section{Figura 17: Pensión media das altas no sistema por tipos. Ano 2015. (Euros)}

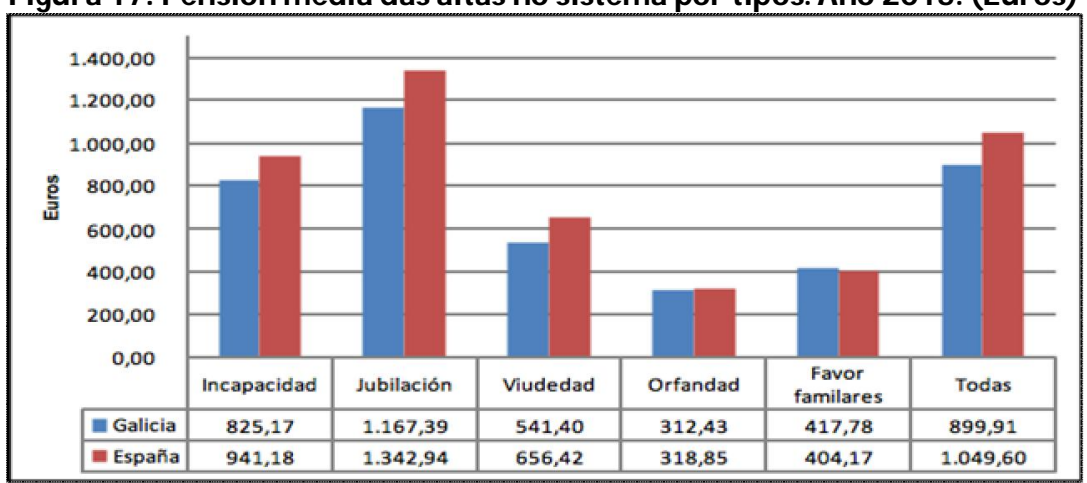

Fonte: elaboración propia a partir do MEESS

Figura 18: Pensión media das baixas no sistema por tipos. Ano 2015. (Euros)

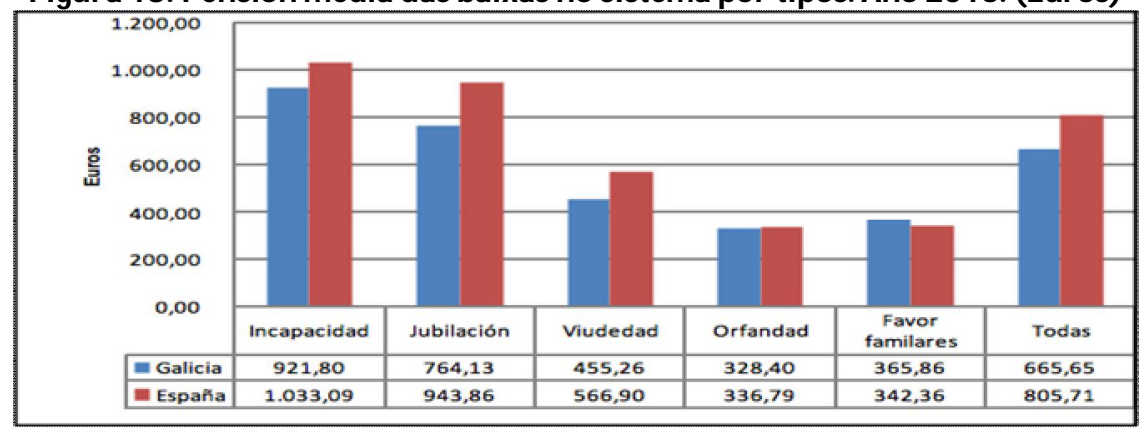

Fonte: elaboración propia a partir do MEESS

Figura 19: Relación pensión media altas/ baixas no sistema por tipos. Ano 2015

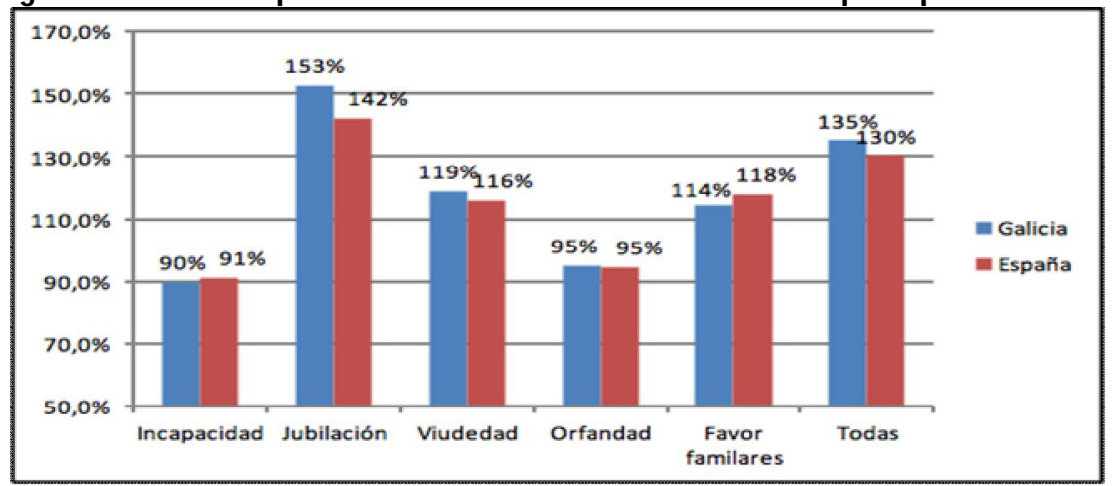

Fonte: elaboración propia a partir do MEESS

Un dos factores que máis incide na contía das pensións é a intensidade das cotizacións realizadas polos futuros pensionistas, polo que nos parece interesante comparar os importes medios das cotizacións e das novas altas de pensións, tanto para o conxunto das 
pensións como para as de xubilación de forma separada, co obxecto de concluír sobre o nivel contributivo do sistema e a súa correlación cos importes das pensións. Na Figura 20 recollemos esa información por comunidades autónomas para o ano 2014. En liñas xerais confírmase o carácter contributivo do sistema, ao ocupar a maioría das comunidades autónomas posicións moi semellantes nos conceptos recollidos, puidendo afirmar, aínda que somos conscientes de que neste exercicio estamos comparando cotizacións e pensións actuais, que unha parte importante das diferenzas antes referidas en relación coas contías das pensións teñen a súa orixe nas distintas intensidades nas cotizacóns.

Figura 20: Cotizacións medias e pensións medias por CCAA. Ano 2014. (Euros)

\begin{tabular}{|c|c|c|c|c|c|}
\hline \multirow{2}{*}{\multicolumn{2}{|c|}{ Cotización media }} & \multicolumn{4}{|c|}{ Pensión media Altas } \\
\hline & & \multicolumn{2}{|l|}{ Todas } & \multicolumn{2}{|c|}{ Jubilación } \\
\hline 1 Pais Vasco & 6.718 .6 & 1 Pais Vasco & $10.790,2$ & País Vaseo & 22.779 .6 \\
\hline 2 Madrid & $6.232,6$ & 2 Asturias & 17.187 .0 & 2 Asturias & $22,036,4$ \\
\hline 3 Navarra & 6.156 .4 & 3 Madrid & $17.099,0$ & 3 Navarra & $20.857,5$ \\
\hline 4 Asturias & 5919,1 & 4 Nawara & $17.090,1$ & 4 Madrid & $20.680,1$ \\
\hline 5 Cataluna & 5.857 .4 & 5 Aragón & 15.637 .3 & 5 Ceuta & 19.973 .7 \\
\hline 6 Cevia & 5.789 .3 & 6 Cantabria & $15,475,2$ & 6 Cantabria & $19.709,2$ \\
\hline 7 Melilla & $5.426,2$ & 7 Cataluna & $15,418,2$ & 7 Aragon & 19.611 .8 \\
\hline 8 Cantabria & $5.398,2$ & 8 Riola, La & $14,956,8$ & 8 Cataluhe & $10.893,0$ \\
\hline 9 Aragón & $5.385,3$ & 9 Castilla y Leon & $14,850,6$ & 9 Castilla y Leon & 18.862 .2 \\
\hline 10 Baleares & $5.347,9$ & 10 Ceuta & $14,482,3$ & 10 Rlola, La & 8205,3 \\
\hline 11 Riola, La & $5.207,0$ & 11 Com. Valenciana & $13,679,1$ & 11 Mellila & 17.451 .7 \\
\hline 12 Castilla yleón & $5.169,0$ & 12 Baleares & $13,460,3$ & 12 Com. Valenciana & 17292,8 \\
\hline 13 com. valenciana & $5.140,4$ & 13 Castlla - La Man. & $12,786,2$ & 13 Castilla - La Man. & 16.530 .9 \\
\hline 14 CALICIA & $5.139,3$ & 14 CALICIA & 12.592 .2 & 14 Murcia & $16.512,9$ \\
\hline 15 Canarias & $4.957,7$ & 15 Canarias & 12565,6 & 15 Baleares & 16425,2 \\
\hline 16 Castila - La Man. & $4.930,8$ & 16 Murcia & $12.53,5$ & 16 CALICIA & 16.157 .4 \\
\hline 17 Murcia & $4.528,6$ & 17 Andalucia & $12.332,5$ & 17 Andalucia & $15.898,4$ \\
\hline 18 Andalutie & $4,462,3$ & 18 Menta & $11.980,1$ & 18 Canarias & $15.869,4$ \\
\hline 19 Extremadura & $4,159,8$ & 19 Extremadura & $11.350,9$ & 19 Extremadura & 14290,2 \\
\hline T. NACIONAL & $5.419,7$ & T. NACIONAL & $14.576,7$ & T. NACIONAL & $18.405,5$ \\
\hline
\end{tabular}

Fuente: zaboracion propia a partir de MEYSS.

Para finalizar coa análise do importe das pensións, cremos interesante correlacionar a súa contía coas rendas obtidas durante a vida laboral, calculando o que se coñece como taxa de substitución do sistema de pensións. Acotamos este exercicio ao RX, ao dispoñer unicamente de información de rendas salariais a través da enquisa anual de estrutura salarial que realiza o Instituto Nacional de Estatística (INE), cuxo ámbito poboacional é equiparable ao cuberto por este rexime.

Na Figura 21 recollemos os salarios medios para os traballadores de 55 anos ou máis, -treito de idade máis próximo a causar a pensión-, e a pensión media das novas altas para o ano 2013 -último con información dispoñible de salarios-. Considerando as 14 pagas mensuais, calculamos a taxa de substitución das novas pensións, situándose esta en Galicia no $63,5 \%$, por enriba da media nacional do $61,8 \%$, debido, principalmente, ao menor salario medio na nosa Comunidade. Constátanse diferenzas significativas entre comunidades autónomas que teñen a súa orixe tanto nos distintos niveles salariais como no desigual peso relativo das modalidades reximes polos que se causan as pensións novas que acceden ao sistema. En todo caso, estas de porcentaxes están en liña co recomendado pola OCED (OECD 2015) respecto de cal debe ser o grao de cobertura salarial das pensións, que o sitúa no $60 \%$. 
Figura 21: Cobertura salarial das pensións. Ano 2013. (Euros)

\begin{tabular}{|c|c|c|c|}
\hline CC.AA. & $\begin{array}{c}\text { Salarios } \\
\text { medlos } \\
55 \text { afhos o más }\end{array}$ & $\begin{array}{l}\text { Pensión media } \\
\text { altas } \\
\text { Régimen general }\end{array}$ & $\begin{array}{c}\text { Tasa } \\
\text { de } \\
\text { sustitución }\end{array}$ \\
\hline Andalucia & $26.521,85$ & 933,64 & $49,28 \%$ \\
\hline Aragon & $24,037,69$ & $1,239,17$ & $72,17 \%$ \\
\hline Asturias & $24,878,04$ & 302,26 & $73,28 \%$ \\
\hline Baleares & $22.714,53$ & 0062,36 & $65,48 \%$ \\
\hline Canatas & $22.307,08$ & 978,14 & $61,39 \%$ \\
\hline Cantabria & $22,083,62$ & 259.53 & $79,85 \%$ \\
\hline Castlla - La Man & $24,075,05$ & 990,39 & $57,59 \%$ \\
\hline Castila y Leon & $22.498,66$ & 203,66 & $74,90 \%$ \\
\hline Cataune & $26,709,89$ & 190,76 & $62.41 \%$ \\
\hline Com, Valenciana & $24.212,45$ & $1.047,22$ & $60,55 \%$ \\
\hline Extemadura & $23,404,91$ & 871,48 & $62,3 \%$ \\
\hline GALICIA & $22,896,0.4$ & $1,039,28$ & $63,55 \%$ \\
\hline Madrio & $26.067,62$ & 1.316 .54 & $65,67 \%$ \\
\hline Nurcia & 25.390 .43 & 974,65 & $83,74 \%$ \\
\hline Navarra & $22.954,45$ & $1,333,13$ & $81,31 \%$ \\
\hline Pals Vasco & $29.643,42$ & 469,62 & $69,4 \%$ \\
\hline Riola: La & $23,332,74$ & $1,166,52$ & $69,99 \%$ \\
\hline T. NACIONAL & $25,631,60$ & $1.132,91$ & $61,88 \%$ \\
\hline
\end{tabular}

Fuente: Eaboracion propha a partir de WE y MeYSS.

\section{RELACIÓN ENTRE AFILIADOS E PENSIONISTAS}

No sistema contributivo da SS, ao tratarse dun sistema de repartimento en virtude do cal as cotizacións que pagan traballadores e empresarios se aplican contemporaneamente ao pago das pensións en vigor en cada momento, a relación entre afiliados e pensionistas é básica para o seu balance financeiro. A relación entre ingresos e gastos do sistema evoluciona en paralelo ao do número de cotizantes e de pensionistas, sempre que se manteñan os parámetros básicos de cálculo das cotizacións e das pensións. A Figura 22 amosa a relación entre afiliados e pensionistas para Galicia e para o conxunto do Estado Español dende o ano 2005, presentando no ano 2015 unha ratio de 1,42 e de 2,03 respectivamente. Apréciase un descenso significativo dende o ano 2008, que comeza a recuperarse moi lixeiramente nos dous últimos anos.

Figura 22: Ratio afiliados / pensionistas

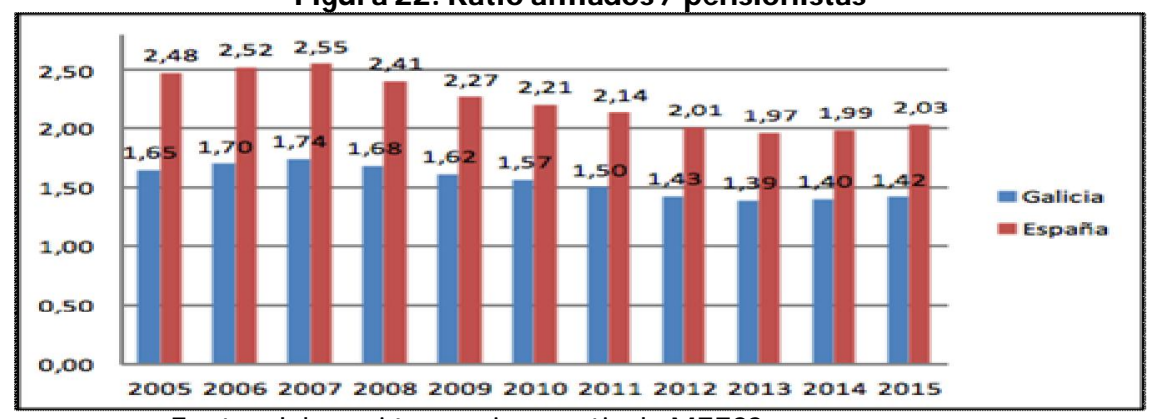

Fonte: elaboración propia a partir do MEESS 
Se cuantificamos a relación de afiliados por pensionista por comunidades autónomas (-ver Figura 23, no Anexo), para o ano 2015-, as diferenzas que obtemos son significativas: deixando á marxe Ceuta e Melilla, polas súas singularidades específicas, destacan Madrid, Baleares e Canarias, con taxas superiores ao 2,55, fronte a Asturias, Galicia e Castela e León, con case a metade desa ratio.

Cremos interesante por en relación os aspectos demográficos do sistema -afiliados e pensionistas- coa estrutura demográfica das diferentes comunidades autónomas para ver as correlacións que se poden establecer. Na Figura 24, no Anexo, recollemos as ratios de afiliados por pensionista e a porcentaxe de poboación de 65 anos e máis con respecto ao total, constatándose unha evidente correlación inversa entre as dúas variables: canto maior é a proporción de poboación avellentada menor é a ratio afiliados-pensionistas. Se ben estes fenómenos son causa un do outro a medio e longo prazo, é de destacar o estreito vencello no momento actual. De novo Asturias, Galicia e Castela e León destacan por compartir un elevado grao de avellentamento da súa poboación conxuntamente con baixas ratios de afiliados-pensionistas, fronte a Madrid, Baleares, Canarias e Murcia, con proporcións inversas.

\section{GASTOS E INGRESOS DO SISTEMA}

Un elemento básico de calquera sistema de pensións é o da súa solvencia e a súa garantía financeira, polo que neste apartado analizaremos os gastos do sistema contributivo da SS poñéndoos en relación coas fontes de financiamento básicas do mesmo.

Iniciamos a análise dos gastos do sistema contributivo da SS recollendo na Figura 25 a evolución do gasto total en pensións, tanto en Galicia como no conxunto do Estado. No ano 2015 o importe das pensións pagadas na Comunidade galega ascendeu a 7.829 millóns de euros, incluíndo os complementos a mínimos, o que representa o 6,8\% do gasto total en pensións do sistema a nivel nacional, que se situou nos 115.068 millóns de euros. Recordemos que o peso da poboación e do número de pensionistas en Galicia con respecto ao total nacional é do $5,86 \%$ e do 7,83\% respectivamente. No que á evolución se refire, dende o ano 2005 o gasto creceu máis no conxunto do Estado que na Comunidade galega, constatándose, tanto nun como noutra, unha baixada no ritmo de crecemento nos últimos anos.

Figura 25: Evolución do gasto en pensións. (Milóns de euros)

\begin{tabular}{|r|r|r|r|r|}
\hline \multirow{2}{*}{ Año } & \multicolumn{2}{|c|}{ Gasto total en pensiones } & \multicolumn{2}{c|}{ Increm. 2005=100 } \\
\cline { 2 - 5 } & \multicolumn{1}{|c|}{ Galicla } & T. Nacional & Galicla & T. Nacional \\
\hline 2005 & $4.951,1$ & $68,950,1$ & 100,0 & 100,0 \\
2006 & $5.253,2$ & $73.725,0$ & 106,1 & 106,9 \\
2007 & $5.648,1$ & $79.805,4$ & 114,1 & 115,7 \\
2008 & $5.974,1$ & $64,728,5$ & 120,7 & 122,9 \\
2009 & $6.301,3$ & $89.886,5$ & 127,3 & 130,4 \\
2010 & $6.657,0$ & $95,701,8$ & 134,5 & 138,8 \\
2011 & $6.899,0$ & $99.533,7$ & 139,3 & 144,4 \\
2012 & $7.132,7$ & $103,503,8$ & 144,1 & 150,1 \\
2013 & $7.443,0$ & $108,564,3$ & 150,3 & 157,5 \\
2014 & $7.658,3$ & $112,170,4$ & 154,7 & 162,7 \\
2015 & $7.829,5$ & $115,068,7$ & 158,1 & 166,9 \\
\hline
\end{tabular}

Fuente: Baboracion propia a partir de MEY SS. 
Se analizamos a distribución do gasto atendendo aos diferentes tipos de pensións -Figura 26-, atopamos que o 70\% correspóndese ao custo das de xubilación, moi por enriba do $60 \%$ que representa o seu número no total de pensións, o $18 \%$ coas de viuvez, fronte ao $25 \%$ do seu peso relativo atendendo ao número de prestacións, o $10 \%$ coas de incapacidade e o $2 \%$ coas de orfandade ou a favor de familiares, estas últimas en liña co que representan con respecto ao número total de pensións.

Figura 26: Distribución do gasto en pensións por tipos. Ano 2015

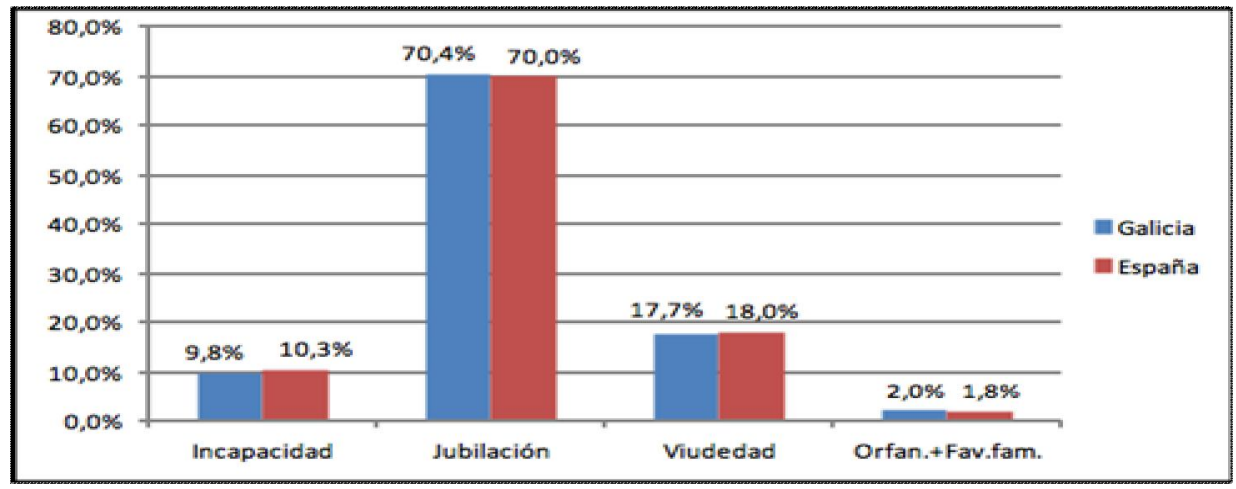

Fonte: elaboración propia a partir do MEESS

Polo que respecta á composición do gasto en pensións atendendo aos diferentes reximes en que son causadas -Figura 27-, en Galicia o 61\% correspóndese co RX, o 26\% co RETA e o 8,5\% co Rexime de Traballadores do Mar, tendo un peso moi pequeno o resto de reximes. A diferenza da distribución por modalidades de pensións, a distribución por reximes presenta diferenzas na Comunidade galega con respecto ao conxunto do sistema, no que o RX representa o $78,4 \%$ do gasto, fronte ao $14,5 \%$ do RETA e o $1,5 \%$ do dos Traballadores do Mar.

Figura 27: Distribución do gasto en pensións por reximes. Ano 2015

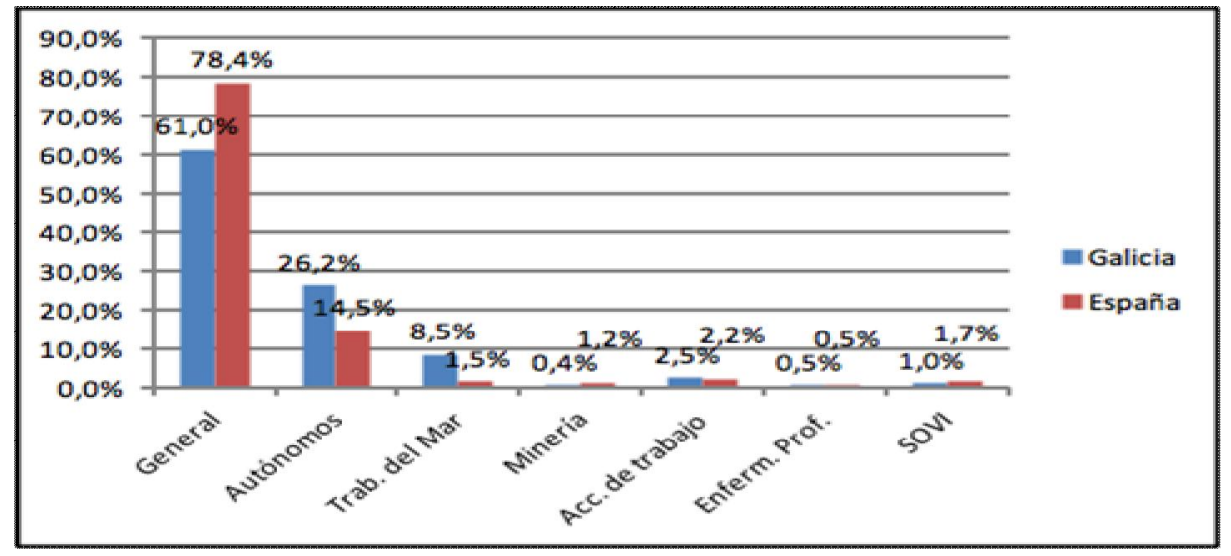

Fonte: elaboración propia a partir do MEESS

Xunto coa contía, estrutura e evolución do gasto en pensións, resulta básico para coñecer a solvencia e a viabilidade do sistema contributivo da SS poñelo en relación cos ingresos. A fonte principal do sistema son as cotizacións sociais, aboadas polas empresas, os traballadores e no Instituto Nacional de Emprego, polas persoas desempregadas que cobran prestacións contributivas. Polo que respecta a estes ingresos, as contías a considerar deben ser as relativas ás continxencias comúns, polas que as empresas cotizan 
un $23,6 \%$ e os traballadores un 4,7\% das bases de cotización no RX. O resto de conceptos polos que se cotiza: desemprego, Fondo de Garantía Salarial (FOGASA), formación profesional e accidentes de traballo e enfermidades profesionais, son ingresos finalistas, que non quedan a disposición da SS para asumir o gasto das prestacións contributivas. Así, coas cotizacións por continxencias comúns, a SS debe facerlle fronte ás pensións contributivas e ao resto de prestacións asumidas, ademais de facer fronte aos gastos de administración e de funcionamiento do sistema. Na Figura 28 recollemos, para os anos 2013 e 2014, os ingresos por cotizacións por continxencias comúns e poñémolos en relación aos gastos nas prestacións contributivas. Con este exercicio centrámonos nos elementos básicos do sistema, debendo ser conscientes de que estamos deixando fóra da comparativa outros ingresos do mesmo, como as taxas, ingresos patrimoniais ou alleamento de investimentos, que no conxunto teñen un peso moi pequeno, pero tamén todos os gastos de estrutura e funcionamiento do sistema.

Ademais, aínda dentro das pensións contributivas do sistema da SS inclúense os complementos a mínimos, dende o ano 2013 estes financíanse completamente con cargo ás cantidades asignadas nos Orzamentos Xerais do Estado e non con cotizacións sociais, polo que nos parece oportuno diferencialos á hora de establecer os saldos.

Os datos do estado financeiro do sistema contributivo da SS, tanto en Galicia como no conxunto do Estado, son moi elocuentes. Deixando de lado o resto de ingresos do sistema, o recadado por cotizacións sociais tan só cobre en Galicia o 66,2\% do gasto en prestacións contributivas, e o 82,6\% no conxunto do sistema, o que dá uns déficits de 2.410 e 18.896 millóns de euros respectivamente no ano 2014. Se a esas cifras lle engadimos os importes correspondentes aos complementos a mínimos, os saldos negativos do sistema elévanse a 3.171 e 6.312 millóns de euros, magnitudes o suficientemente representativas das dificultades financeiras do sistema no momento actual e a situación agravada en Galicia a este respecto.

Figura 28: Ingresos e gastos do sistema contributivo da SS. (Millóns de euros)

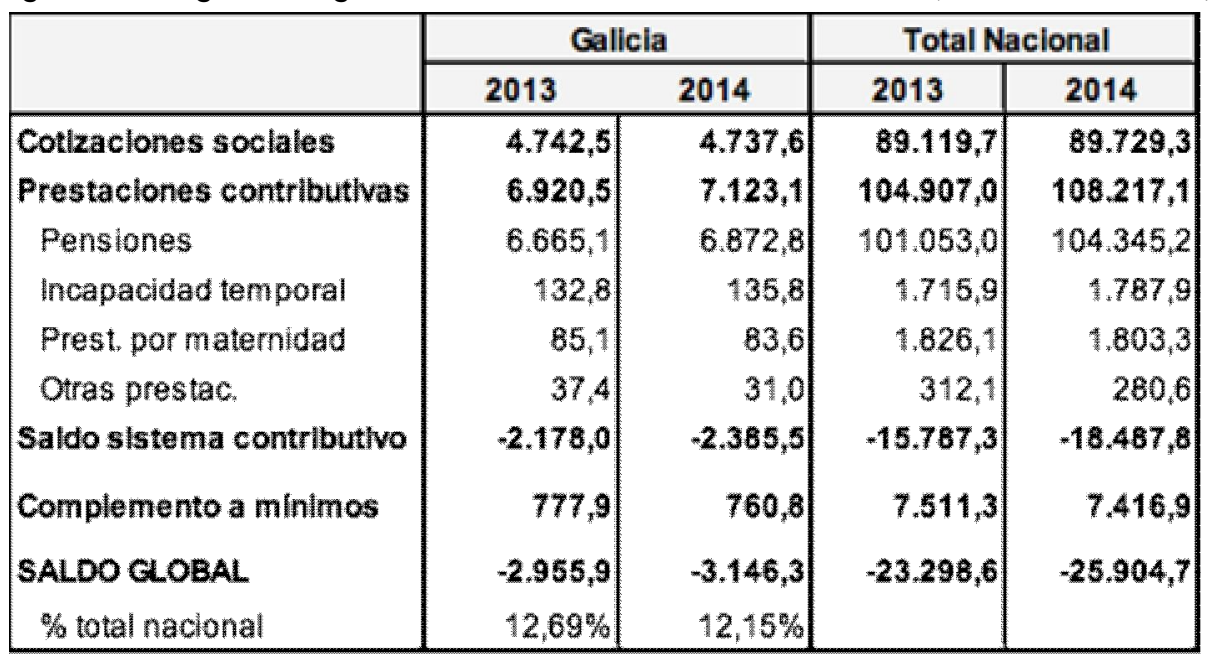

Fuente: Eaboración propia a partir de MEYSS.

Para profundar na solvencia financeira do sistema, analizamos a distribución territorial dos ingresos e gastos para as diferentes comunidades e cidades autónomas e cuantificamos os saldos, en valores absolutos e por afiliado, tanto para o conxunto do sistema como para o RX e o RETA -Figuras 29a, 29b y 29c no Anexo-. 
Deixando á marxe Ceuta e Melilla, que en todas as variables do sistema presentan unha realidade moi diferenciada, no ano 2014, último para o que se dispón de datos de ingresos por cotizacións de forma territorializada, tan só en Baleares, Madrid e Canarias os ingresos por cotizacións eran superiores aos gastos en pensións, sen incluír os importes dos complementos a mínimos nin o resto de prestación contributivas por continxencias comúns. No total do sistema o grao de cobertura era do 86\%, destacando Asturias, Cantabria, Castela e León e Galicia como as comunidades nas que as porcentaxes de cobertura do gasto en pensións cos ingresos por cotizacións son máis baixos. Se os saldos se individualizan por afiliado, atopamos diferenzas aínda máis importantes, con superávits na contorna dos 700-800 euros por afiliado nas tres comunidades con saldos positivos, fronte a déficits por afiliado que acadan os 6.169 euros en Asturias ou os 2.316 euros en Galicia.

Tendo en conta a relación entre afiliados e pensionistas que analizamos no apartado anterior, e amosamos na Figura 22, pódese concluír que no momento actual só as comunidades cunha ratio de afiliados-pensionistas superior a 2,4 conseguen saldos equilibrados ou positivos, debendo ser ese o obxecivo para garantir a viabilidade do sistema. Neste senso, recollemos na última fila das Figuras 29 a porcentaxe de incremento das cotizacións ou do número de afiliados necesarios para cubrir cos ingresos os gastos en pensións. De novo plásmanse nesta variable as diferenzas antes comentadas, sendo necesario un incremento dos ingresos no conxunto do sistema do 16,3\% e do $45,1 \%$ en Galicia.

Se individualizamos esta comparativa de ingresos e gastos para o RX e o RETA, constatamos que os maiores desequilibrios e diferenzas territoriais prodúcense a nivel do Rexime de Autónomos, no que Galicia presenta o maior desequilibrio de todas as comunidades, tanto en termos absolutos como relativos. Se o equilibrio tivera que se dar a nivel do rexime no que se causan as pensións, os ingresos en Galicia no RETA, xa fose vía incremento das cotizacións ou do número de afiliados, deberían aumentar un $142 \%$ fronte ao $41 \%$ a nivel nacional. Esta diferenza ten a súa orixe en que nese rexime se integran agora todos os pensionistas que no seu día causaron ou cotizaron pensión no rexime especial agrario por conta propia, non existindo actualmente a correspondencia necesaria co número de cotizantes no RETA.

Malia que esta imputación rexional de ingresos e gastos, coa súa correspondente cuantificación de saldos, axuda ao coñecemento da realidade do sistema a nivel territorial, os seus resultados deberían ser matizados no senso de que pensións atribuídas a unha comunidade autónoma puideron ser causadas con traballo e cotizacións noutra, polo que, nunha estrita segregación do sistema, deberían ser cobertas coas actuais cotizacións recadadas nesta última. Este fenómeno, do que non dispoñemos de información publicada, afecta claramente a Galicia, que conta cun número importante de pensionistas que causaron a súa pensión traballando como emigrantes noutros territorios de España.

\section{DISTRIBUCIÓN REXIONAL DO GASTO EN PENSIÓNS}

Para completar a análise do sistema público de pensións, e coa finalidade de profundar nos elementos diferenciais que dentro do mesmo presenta Galicia, parécenos oportuno recoller algúns indicadores da distribución xeográfica do gasto en pensións contributivas no Estado español.

Neste senso, unha ratio que pode ser indicativa desa distribución é o gasto por habitante en cada circunscrición, que recollemos na Figura 30 para o ano 2015. O gasto medio a escala nacional foi de 2.468 euros, con nove comunidades superando esa media, entre as que se atopa Galicia, con 2.865 euros por habitante. As que teñen esa ratio máis elevada 
son Asturias -con 4.160 euros-, País Vasco -con 3.708 euros- e Cantabria -con 3.009 euros, namentres que as que a presentan máis reducida, ademais de Melilla e Ceuta, son Canarias -con 1.593 euros-, Murcia -con 1.772 euros- e Baleares -con 1.864 euros-. Presentan menor gasto por habitante as comunidades cunha maior ratio de habitantes por pensionista, que é a variable que condiciona, en termos xerais, a ordenación resultante. Aínda que non plasmamos os resultados desta ratio nun mapa de España, pódese concluír que hai unha distribución xeográfica do gasto, segundo a cal, este é máis elevado, en termos per cápita, nas comunidades do norte de España.

\section{Figura 30: Gasto en pensións por habitante por comunidades autónomas. Ano 2015. (Euros)}

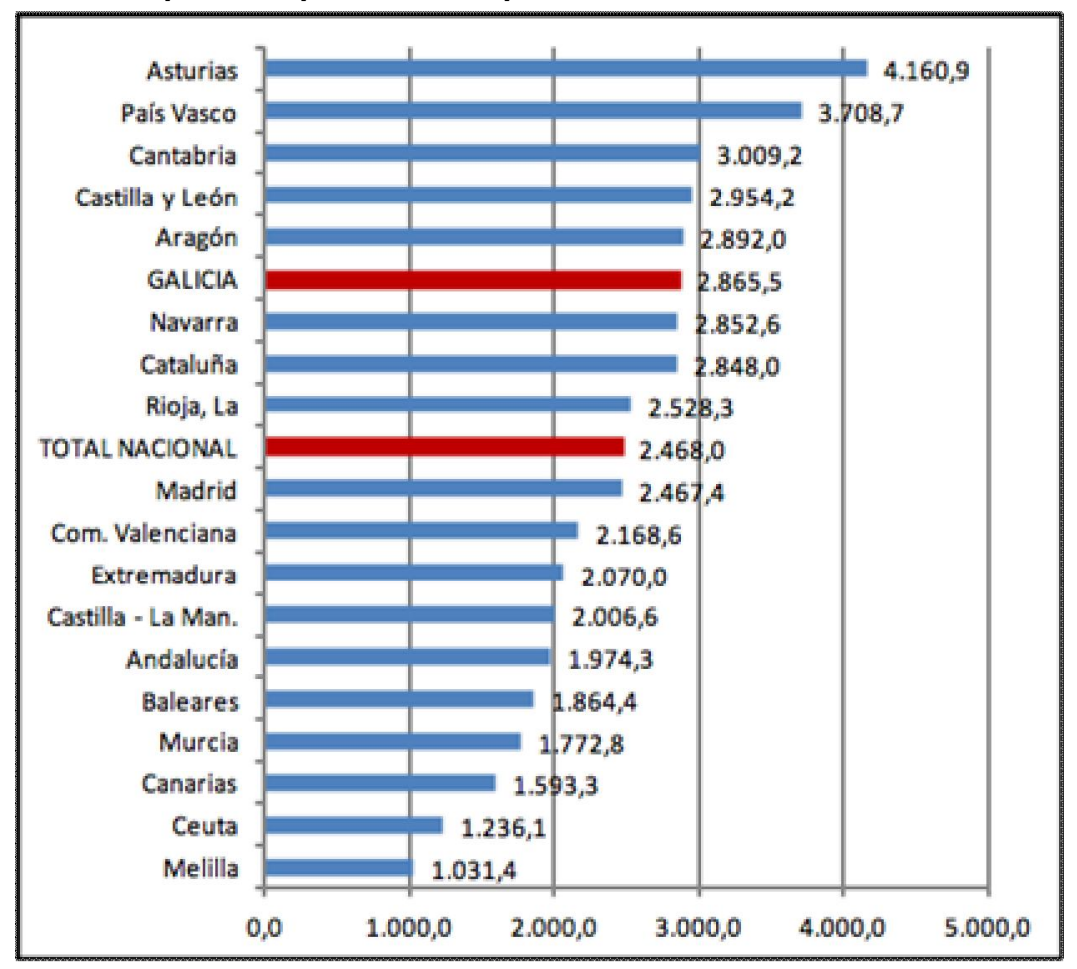

Tamén resulta indicativo da distribución territorial do gasto en pensións a análise da súa correlación coa riqueza rexional, para o que calculamos na Figura 31 a porcentaxe que representa en cada comunidade autónoma o gasto en pensións en relación co seu Produto Interior Bruto (PIB), no ano 2014. Con respecto á clasificación das comunidades segundo o gasto por habitante constátase unha reordenación, perdendo posicións as comunidades máis ricas en favor das de menor PIB por habitante. O gasto en pensións contributivas no conxunto do sistema, incluíndo os complementos a mínimos, representaba o 10,7\% do PIB nacional, presentando dez comunidades porcentaxes superiores a esa media, con Asturias á cabeza, cunha ratio do 20,6\%, figurando Galicia en terceiro lugar, co 14,2\%. Pola contra, Baleares, Madrid e Canarias, son as comunidades nas que o gasto en pensións teñen menos peso en relación ao PIB, con porcentaxes por debaixo do 8\%.

Para profundar nesta análise da distribución xeográfica do gasto en pensións procedemos a calcular algúns indicadores de proporcionalidade, como os utilizados por Ayala e Martínez (1991) para analizar os efectos distributivos do gasto público en España e que, posteriormente, foron aplicados por Gómez-Sala e Sánchez-Maldonado (2000) ao gasto en pensións. 
Figura 31: Gasto en pensións en porcentaxe do PIB por comunidades autónomas. Ano 2014

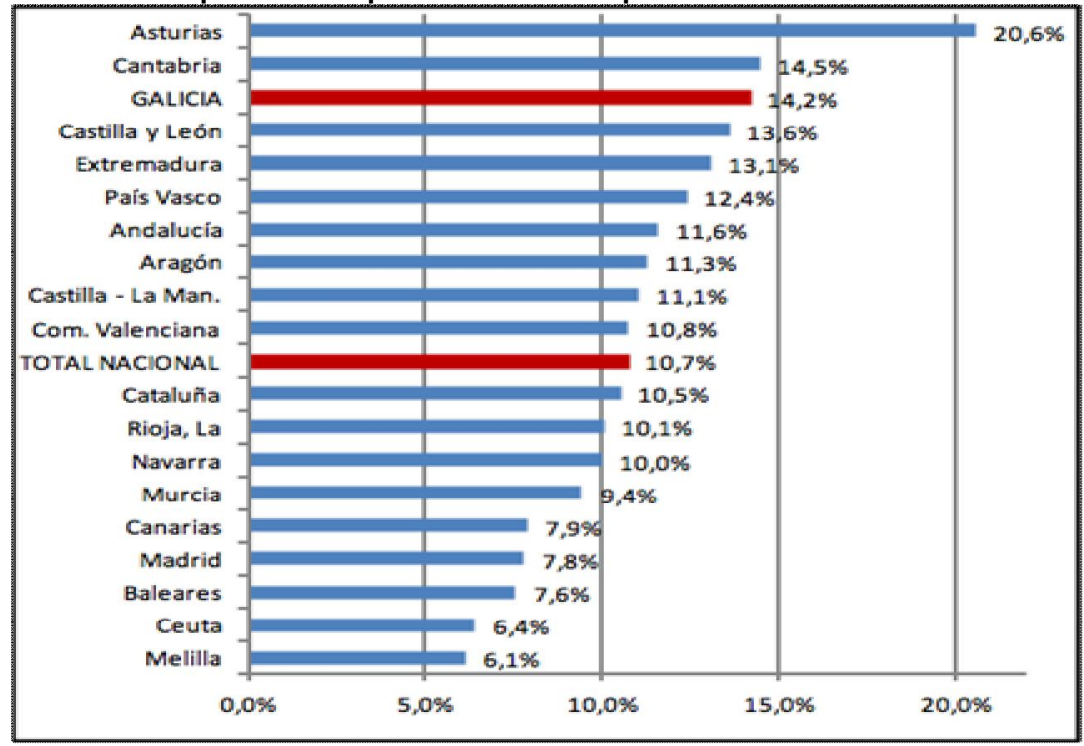

Un primeiro índice é o que mide a proporción que garda o peso do gasto en pensións contributivas en relación co peso relativo da poboación en cada comunidade autónoma ( $I P P a b_{i}$ ) resultado da expresión (1) na que $G P_{i}$ e $P o b_{i}$ son o gasto total en pensións contributivas e a poboación respectivamente na comunidad autónoma $i$. Un valor igual a un deste índice para todas as rexións equivalería á liña diagonal da curva de Lorenz, que indica unha distribución igualitaria a nivel das comunidades autónomas do gasto en pensións contributivas. Outro indicador relevante da distribución rexional do gasto en pensións é o que compara a distribución do gasto en pensións por comunidades e a distribución rexional do PIB a prezos de mercado ( $\left.I P P_{i} b_{i}\right)$ calculado en (2).

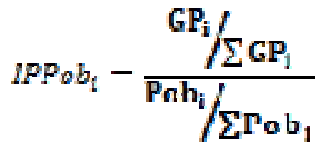

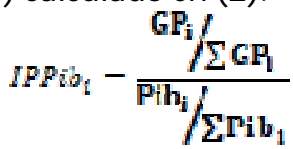

(2)

onde $P i b_{i}$ é o PIB a prezo de mercado da comunidad autónoma $i$.

Na Figura 32, no Anexo, recollemos os resultados destes cálculos, ordenando as comunidades autónomas polos valores destes índices e incluíndo a diferenza dos mesmos entre os anos 2005 e 2014. O primeiro aspecto a resaltar, en liña co resto de indicadores analizados previamente, é a falta de proporcionalidade ou a elevada disparidade, que presenta o repartimento do gasto en pensións contributivas en relación á distribución da poboación e do PIB, a pesar de que a proporcionalidade debería, ata certo punto, ser un dos principios básicos dun sistema de repartimento.

Polo que respecta á poboación, temos comunidades autónomas nas que o gasto en pensións supera nun $69 \%$ ao peso da poboación , como ocorre en Asturias, fronte a comunidades nas que tan só chega ao $64 \%$ do seu peso, como ocorre en Canarias. Galicia presenta un índice de proporcionalidade do gasto en pensións en relación coa poboación do 1,162 .

En relación coa proporcionalidade do gasto en pensións e o PIB, as que maiores índices presentan son Asturias, Cantabria, Galicia -cun 32\% superior do gasto con relación ao PIB-, e Castela e León, que xustamente coinciden coas que maiores saldos negativos presentan ao correlacionar ingresos e gastos do sistema, como vimos no apartado 
anterior. Á súa vez, as que menores índices presentan, deixando á marxe Ceuta e Melilla, son Baleares, Madrid e Canarias, que son as únicas que presentan saldos positivos. Existe, por tanto, unha correlación inversa entre o índice de proporcionalidade do PIB e os saldos entre ingresos e gastos do sistema: a maior índice, maior saldo negativo e ao contrario.

Parece evidente a conclusión de que o sistema público contributivo de pensións en España presenta unha forte dispersión territorial dos seus indicadores que, sumados, dan lugar a unha importante solidariedade territorial entre as diferentes rexións. Solidariedade que está relacionada máis coa demografía que co nivel de riqueza, e baseáse nunha redistribución dos ingresos por cotizacións, en virtude da cal as comunidades rexuvenecidas financian ás avellentadas. Así, existen rexións ricas que son beneficiarias desta solidariedade tanto como outras rexións menos ricas, permitindo o sistema de caixa único cubrir as pensións das rexións máis avellentadas, como é o caso de Galicia.

\section{CONCLUSIÓNS}

O sistema público de pensións é uno dos elementos fundamentais que configuran o estado de benestar en España. A crise económica que sofre a economía española dende finais da primeira década dos anos 2000 abriu un intenso debate sobre ata que punto o sistema resulta sostible e, no seu caso, que reformas son necesarias para que así sexa. Malia que neste traballo unicamente analizamos a realidade actual dos ingresos e gastos do sistema contributivo de pensións español, sen facer proxeccións futuras dos elementos que o configuran, podemos concluír, de forma meridianamente clara, que os desequilibrios que presenta o sistema van máis aló da evolución do mercado de traballo durante o actual período de crise, e comeza a ser o resultado dunha realidade demográfica, estrutural a medio e longo prazo, que será determinante para a viabilidade económica futura do sistema.

A anterior conclusión, facilmente constatable da análise que neste traballo facemos dos distintos elementos que configuran o sistema público de pensións en España, é máis evidente, se cabe, cando singularizamos ese estudo para o ámbito da Comunidade Autónoma de Galicia, que presenta elementos diferenciais negativos dentro do sistema único no que se integra a nivel estatal. Os devanditos aspectos diferenciais teñen a súa orixe, en parte, na estrutura económica e laboral, pasada e presente, se ben cobra cada vez máis peso a configuración e dinámica da poboación galega, verdadeiro condicionante da evolución futura do sistema de pensións.

Neste senso, debemos resaltar que o $24,3 \%$ do total da poboación galega ten a condición de pensionista, o que supón seis puntos máis que no conxunto do Estado, xerando un gasto en pensións equivalente ao $14,2 \%$ do PIB, fronte ao $10,7 \%$ no total do sistema. Este maior peso do gasto en pensións non ten o seu correspondente reflexo na contía das pensións medias, presentando Galicia o segundo importe máis baixo das comunidades autónomas, necesitando ademais que o 33\% das pensións galegas sexan complementadas para garantir os mínimos legalmente establecidos. Con todo, Galicia é unha das comunidades autónomas máis beneficiadas do importante grao de solidariedade territorial que presenta o sistema público de pensións contributivas español.

Na análise do sistema de pensións contributivo, na medida en que é un sistema de repartimento, resulta básico analizar a correlación existente en cada momento temporal entre o número de afiliados, que sosteñen as pensións coas súas contribucións, e os pensionistas beneficiarios. Nesta variable constátanse os efectos da crise económica, pasando a relación de afilados-pensionista de 2,55 no ano 2007 a 2,03 no ano 2015 para o conxunto do sistema, e do 1,74 ao 1,42 en Galicia durante o mesmo período. Cando confrontamos os ingresos e os gastos directamente ligados á parte contributiva para as 
diferentes comunidades autónomas, obtemos como resultado que son necesarias ratios superiores a 2,4 para equilibrar ingresos e gastos no momento actual.

Esta relación entre afiliados e pensionistas xera un desequilibrio, atendendo exclusivamente aos ingresos e gastos directamente relacionados coa parte contributiva do sistema, de 18.487 millóns de euros no total do sistema, dos cales 2.385 son imputables á Comunidade Autónoma de Galicia. A estas cifras, para completar o conxunto do sistema público de pensións en España, habería que sumarlle os gastos derivados dos complementos a mínimos, das pensións non contributivas e do sistema de Clases Pasivas, que se financian con cargo aos Orzamentos Xerais do Estado. Malia que o sistema da SS conta con outros ingresos, ademais dos estritamente derivados das cotizacións, estes non permitiron cubrir o desfasamento antes referido, xerándose un déficit total no ano 2014 de 11.202 millóns de euros.

Este desequilibrio tan importante do balance financeiro do actual sistema de pensións en España, evidencia un problema estrutural que ameaza a súa viabilidade futura nas condicións actuais. As necesidades de ingresos adicionais, ben sexa polo incremento do número de cotizantes ou da contía das cotizacións, son de tal magnitude que dificilmente se verán reducidas coas modificacións introducidas nas reformas operadas no sistema nos anos 2011 e 2013 que, en resumo, empeoran e reducen as condición nas que se causan as pensións e a súa contía. Os efectos da dinámica demográfica superarán o resultado destas reformas e os posibles incrementos nos ingresos derivados dunha mellora no mercado laboral, sendo necesario abrir un debate fundamentado nas análises técnicas, e transparente para a cidadanía, sobre a realidade futura do sistema público de pensións en España.

\section{BIBLIOGRAFÍA}

DÍAZ-GIMÉNEZ, J. (2014): “Las pensiones europeas y sus reformas recientes”, Documento de Trabajo № 7/ 2014, Instituto BBVA de Pensiones.

GÓMEZ SALA, J.S. y SÁNCHEZ MALDONADO, J. (2000): “La geografía de la Seguridad Social española desde una perspectiva de ciclo vital”, Hacienda Pública Española, monografía: Las pensiones en España, Instituto de Estudios Fiscales, págs. 149-152.

GÓMEZ SALA, J.S. y SÁNCHEZ MALDONADO, J. (2007): "Seguridad Social y Comunidades Autónomas", Revista de Estudios Regionales, № 78, págs. 231-259.

HERCE SAN MIGUEL, J.A. (2015): “Las pensiones en las Comunidades Autónomas”, Documento de Trabajo № 12/15, Instituto BBVA de Pensiones.

HERCE SAN MIGUEL, J.A. y VENTURA BRAVO, J.M. (2014): "Las pensiones en España y Portugal", Documento de Trabajo № 2/2014, Instituto BBVA de Pensiones.

INE (2016): Cuentas Económicas. Contabilidad Regional de España, base 2010.

INE (2016): Encuesta anual de estructura salarial, 2013.

INE (2016): Padrón. Población por municipios, año 2015.

LÓPEZ GOLPE, J. y REIG BOTELLA, A. (2014): “O sistema público de pensións”, Revista Galega de Economía, vol. 23, núm. 1, págs. 115-136.

MEYSS (2016): Estadísticas de Afiliación. Ministerio de Hacienda y Seguridad Social https://w6.segsocial.es/ PXWeb/ pxweb/ es/ ?rxid=dc1fdb9f-0356-46ca-aee7-508d9ffc10bb.

MEYSS(2016): Estadísticas de Pensiones, https:// w6.seg-

social.es/ ProsaInternetAnonimo/OnlineAccess?ARQ.SPM.ACTION=LOGIN\&ARO.SPM.APPTYPE=SERVICE \&ARQ.IDAPP=ESTA0001.

MEYSS (2016): Estadísticas, Presupuestos y Estudios, http://www.segsocial.es/ Internet 1/Estadistica/index.htm.

MEYSS(2016): Información $\quad$ Económico Financiera, $\underline{\text { http://www.seg- }}$ social.es/Internet 1/InformacionEconomicof/index.htm.

OECD (2015): Pensions at a Glance 2015, OECD.

OECD (2014): Pensions Outlook 2014, OECD.

UTRILLA DE LA HOZ, A. (2006): "El balanç de la Seguretat Social i de les pensions per comunitats autònomes", Nota d'economia 85, 2n quadrimestre, págs. 45-54.

Anexo on line: https://ideas.repec.org/s/sdo/regaec.html 